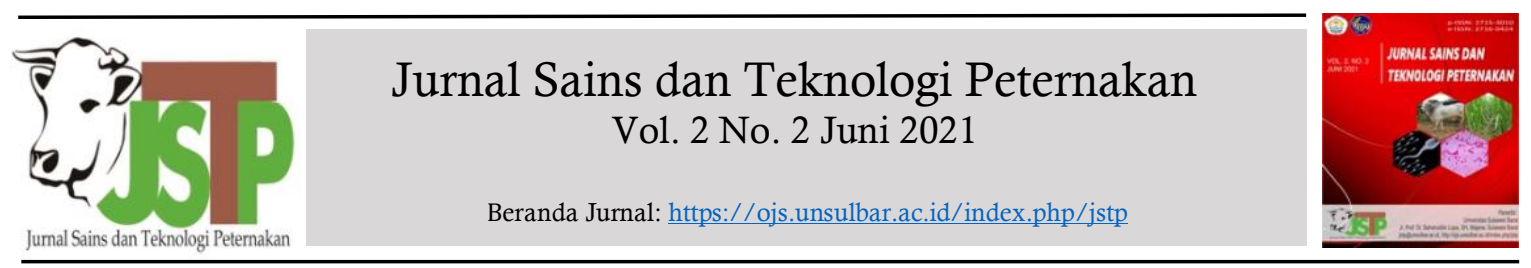

\title{
Studi Kasus: Canine Chronic Ulcerative Stomatitis pada Anjing Pomeranian
}

\author{
(Case Study: Canine Chronic Ulcerative Stomatitis on Pomeranian Dog) \\ Zumara Mufida Hidayati ${ }^{1^{*}}$, I Nyoman Suartha ${ }^{2}$, I Gede Soma ${ }^{2}$ \\ ${ }^{1}$ Program Pendidikan Profesi Dokter Hewan, Fakultas Kedokteran Hewan, Universitas Udayana, Jl. Sudirman, \\ Sanglah, Denpasar, Bali, Indonesia 80234. \\ ${ }^{2}$ Laboratorium Ilmu Penyakit Dalam Veteriner, Fakultas Kedokteran Hewan, Universitas Udayana, Jl. Sudirman, \\ Sanglah, Denpasar, Bali, Indonesia 80234.
}

\begin{tabular}{l} 
A R T I C L E I N F O \\
Received: 18 Februari 2021 \\
Accepted: 30 Mei 2021 \\
*Corresponding author \\
zumaramufida@gmail.com \\
\\
Keywords: \\
Canine chronic ulcerative \\
Dental Plaque \\
Halitosis \\
Stomatitis \\
\hline
\end{tabular}

Kata Kunci:

Canine chronic ulcerative

Halitosis

Plaque gigi

Stomatitis

\begin{abstract}
A B S T R A C T
Chronic inflammation of the oral cavity accompanied by ulcers called Canine Chronic Ulcerative Stomatitis (CCUS). A Pomeranian dog was examined at the Animal Hospital, Faculty of Veterinary Medicine, Udayana University with complaints of decreased appetite and drinking accompanied, in the dog that would not close his mouth. Clinical examination showed that there is bleeding and swelling of the gums and lips, torn sores and ulcer on the lower lip, redness on the edge of the tongue, blackish plaque in almost all of his teeth, halitosis, and enlargement of the mandibular lymph nodes, and routine hematological examination showed a normochromic and normocytic anemia, elevated monocyte levels, and neutrophilia, so dogs were diagnosed with CCUS. Treatment using Amoxicillin, Meloxicam, Vitamin C, Ferrous Sulfate, and fluid therapy using $\mathrm{NaCl}$ initially gave quite good results, but the dog died on the sixth day after therapy which possibly due to severe malnutrition and anemia.
\end{abstract}

\section{A B S T R A K}

$\overline{\text { Radang rongga mulut yang berlangsung kronis disertai ulser disebut }}$ Canine Chronic Ulcerative Stomatitis (CCUS). Seekor anjing Pomeranian diperiksa di Rumah Sakit Hewan, Fakultas Kedokteran Hewan, Universitas Udayana dengan keluhan nafsu makan dan minum menurun, di anjing yang tidak mau menutup mulutnya. Hasil pemeriksaan klinis menunjukkan bahwa terdapat perdarahan dan pembengkakan pada gusi dan bibir, luka sobek dan ulser pada bibir bawah, kemerahan pada tepi lidah, plaque berwarna kehitaman di hampir seluruh giginya, halitosis, serta pembesaran limfonodus mandibularis, dan pemeriksaan hematologi rutin menunjukkan adanya anemia normositik normokromik, peningkatan kadar monosit, dan neutrofilia, sehingga anjing didiagnosa menderita CCUS. Pengobatan dengan menggunakan Amoxicilin, Meloxicam, Vitamin C, Ferrous Sulfate, dan terapi cairan $\mathrm{NaCl}$ awalnya memberikan hasil cukup baik, namun hewan meninggal dunia di hari keenam pasca terapi yang kemungkinan dikarenakan malnutrisi dan anemia parah. 


\section{Pendahuluan}

Radang rongga mulut disertai ulcer yang berlangsung kronis disebut Canine Chronic Ulcerative Stomatitis (CCUS), yang juga dikenal dengan chronic ulcerative stomatitis, ulcerativ stomatitis, idiopathic stomatitis, atau lymphocyticplasmacytic stomatitis merupakan penyakit yang ditandai dengan adanya lesi ulser yang tersebar pada mukosa mulut dan bibir yang dapat menjadi nekrosis (Boutoille \& Hennet, 2011). Menurut Anderson, Peralta, Kol, Kass, \& Murphy (2017), lesi ulser terdapat di gusi dan lapisan mukosa pipi bagian dalam. Selain itu, ulser juga sering ditemukan di tepi lidah, langitlangit rongga mulut, atau di lapisan mukosa bibir. Faktor penyebab terjadinya penyakit tersebut adalah adanya tingkat stres menyebabkan anjing lebih sering terinfeksi agen penyakit. Patogenesis dari CCUS terjadi akibat adanya akumulasi plaque gigi yang mengandung microbiota sangat kompleks, yang baik secara langsung atau tidak langsung menyebabkan peradangan dan ulserasi pada lapisan mukosa.

CCUS merupakan penyakit yang cukup membuat frustasi bagi pemilik hewan maupun dokter hewan. Hal ini dikarenakan kondisi yang menyakitkan dan sering menyebabkan disoreksia pada hewan penderita (Boutoille \& Hennet, 2011). Berdasarkan uraian tersebut, maka kajian ilmiah pada anjing dibutuhkan untuk mengetahui penanganan Canine Chronic Ulcerative Stomatitis, evaluasi pengobatan, dan strategi pengendaliannya. Laporan kasus ini membahas tentang kasus Canine Chronic Ulcerative Stomatitis dan penanganannya pada anjing Pomeranian.

\section{Materi dan Metode}

\subsection{Sinyalemen}

Anjing bernama Piki, ras Pomeranian, jenis kelamin jantan, umur 2 tahun, berat badan $2 \mathrm{~kg}$. Anjing mengalami kebotakan rambut di seluruh tubuhnya, serta warna kulitnya putih dan hitam. Pemilik anjing ini adalah Ibu Ari yang beralamat di Batubulan, Gianyar, Bali.

\subsection{Anamnesa}

Anjing Pomeranian berumur \pm 2 tahun. Awalnya, klien melihat air minum dalam wadah yang diberikan berubah warna menjadi kuning keruh, hal ini disertai dengan nafsu makan anjing yang menurun dan sudah berlangsung selama \pm 5 hari, setelah diperiksa rongga mulutnya ternyata terdapat perdarahan pada gusi anjing tersebut. Dua hari kemudian, kondisi anjing tersebut semakin parah ditandai dengan adanya tambahan luka di bibir dan ulser sehingga mulut anjing tidak mau menutup dengan sempurna dan air liur terlihat menetes berwarna kuning kemerahan. Selain itu, anjing memiliki bau mulut yang sangat busuk. Biasanya, anjing memakan makanan sisa dari pemilik, terkadang juga memakan makanan sisa yang ada di tempat sampah, namun sudah sekitar 10 hari anjing diberi pakan dryfood. Anjing diberi air minum yang berasal dari air PAM, dipelihara secara dilepasliarkan di lingkungan rumahnya, tidak pernah dimandikan, ataupun digosok giginya. Selain itu, anjing juga mengalami masalah pada kulitnya yakni gatal-gatal dan disertai kerontokan rambut yang sudah berlangsung selama kurang lebih 5 bulan, namun belum pernah diberikan pengobatan.

\subsection{Pemeriksaan Fisik dan Status Present}

Pemeriksaan fisik dan status present dilakukan berdasarkan metode Widodo et al. (2011) untuk mengidentifikasi tanda-tanda klinis yang ada pada hewan kasus, yakni frekuensi denyut jantung, pulsus, respirasi, Capillary Refill Time, dan suhu.

\subsection{Pemeriksaan laboratorium}

\section{Pemeriksaan Darah}

Pengambilan sampel darah dilakukan di vena Cephalica antebrachii dorsalis, yaitu vena yang berada di kaki depan. Darah diambil sebanyak 2 $\mathrm{ml}$ menggunakan dysposable syringe $3 \mathrm{ml}$. Sampel darah yang telah terambil kemudian dimasukkan ke dalam tabung penampung yang mengandung antikoagulan untuk selanjutnya diperiksa menggunakan Auto Hematology Analizer.

\section{Diagnosa dan Prognosa}

Berdasarkan anamnesa, pemeriksaan klinis, dan pemeriksaan laboratorium, maka anjing kasus Piki ras Pomeranian berumur 2 tahun yang mengalami perdarahan dan pembengkakan pada bibir, luka sobek dan ulser pada bibir bawah, kemerahan pada tepi lidah, serta akumulasi plaque berwarna kehitaman di giginya didiagnosa Canine Chronic Ulcerative Stomatitis dengan prognosa dari penyakit ini adalah fausta, yaitu dapat disembuhkan.

\section{Penanganan}

Penanganan kasus Canine Chronic Ulcerative Stomatitis ini terapi yang diberikan pada anjing Piki yaitu terapi causatif, simptomatif, dan 
supportif. Terapi causatif yang diberikan yaitu antibiotik Amoxicilin per oral $(40-80$ $\mathrm{mg} / \mathrm{kgBB} / 12$ jam selama 5 hari), Meloxicam per oral $(2,5-3,5 \mathrm{mg} / \mathrm{kgBB} /$ hari selama 5 hari $)$ sebagai terapi simptomatif, Ferrous sulfat (100$300 \mathrm{mg} /$ hari selama 7 hari) dan Vitamin C per oral (100 - $500 \mathrm{mg} /$ hari selama 5 hari), dan infus $\mathrm{NaCl}$ secara intavena sebagai terapi supportif. Selain itu, juga dilakukan pembersihan rongga mulut menggunakan larutan antiseptik kumur untuk membantu menjaga kebersihan rongga mulut anjing tersebut.

\section{Hasil dan Pembahasan}

Hasil pemeriksaan status present (Tabel 1) diperoleh frekuensi denyut jantung dan pulsus hewan kasus yakni $160 \times /$ menit. Hal ini menunjukkan adanya peningkatan frekuensi denyut jantung dan pulsus. Peningkatan frekuensi denyut jantung maupun pulsus pada hewan penderita CCUS ini terjadi karena kondisi hewan yang terkejut dan tidak nyaman saat pemeriksaan berlangsung akibat rasa nyeri yang timbul. Hal ini sesuai dengan pernyataan Widodo et al. (2011) bahwa peningkatan frekuensi denyut jantung dan pulsus dapat terjadi karena kondisi hewan terkejut atau setelah hewan beraktivitas. Hasil pemeriksaan status present juga menunjukkan bahwa CRT anjing kasus mengalami perlambatan, yakni $>2$ detik. Belum ada laporan kasus perlambatan CRT pada ajing, akan tetapi laporan perlambaran CRT pada hewan lain telah dilaporkan. Graves \& Ivey (2018) melaporkan bahwa CRT pada kuda penderita Ulcerative stomatitis mengalami perlambatan, yakni 3 detik. Perlambatan CRT ini dapat terjadi karena hewan mengalami dehidrasi, hal ini sesuai pernyataan Fleming et al. (2015) bahwa CRT yang lambat merupakan tanda dari dehidrasi, dimana dehidrasi yang terjadi merupakan dampak dari berkurangnya konsumsi air pada penderita CCUS.

Tabel 1. Hasil pemeriksaan status present hewan kasus

\begin{tabular}{lllll}
\hline No. & Jenis pemeriksaan & Hasil & Nilai normal* & Keterangan \\
\hline 1. & Jantung $(\times /$ menit $)$ & $160 \times /$ menit & $90-120$ & Meningkat \\
2. & Pulsus $(\times /$ menit) & $160 \times /$ menit & $90-120$ & Meningkat \\
3. & Capillary Refill Time (CRT) (detik) & $>2$ detik & $<2$ & Melambat \\
4. & Respirasi $(\times /$ menit) & $24 \times /$ menit & $20-30$ & Normal \\
5. & Suhu $\left({ }^{\circ} \mathrm{C}\right)$ & $38,8^{\circ} \mathrm{C}$ & $38,5-39,5$ & Normal \\
\hline
\end{tabular}

*Sumber: Widodo et al. (2011).

Tabel 2. Hasil pemeriksaan klinist hewan kasus

\begin{tabular}{|c|c|c|c|}
\hline No & Jenis Pemeriksaan & Hasil & Keterangan \\
\hline 1 & Kulit dan Kuku & Tidak Normal & $\begin{array}{l}\text { Rambut mengalami kerontokan dan terdapat } \\
\text { lesi scale di beberapa bagian tubuhnya }\end{array}$ \\
\hline 2 & Anggota Gerak & Normal & - \\
\hline 3 & Muskuloskeletal & Normal & - \\
\hline 4 & Syaraf & Normal & - \\
\hline 5 & Sirkulasi & Normal & - \\
\hline 6 & Urogenital & Normal & - \\
\hline 7 & Respirasi & Normal & - \\
\hline 8 & Pencernaan & Tidak Normal & $\begin{array}{l}\text { Terdapat perdarahan dan pembengkakan } \\
\text { pada bibir, luka sobek dan ulser pada bibir } \\
\text { bawah, kemerahan pada tepi lidah, dan } \\
\text { plaque gigi }\end{array}$ \\
\hline 9 & Mukosa & Tidak Normal & $\begin{array}{l}\text { Terdapat perdarahan dan ulser pada mukosa } \\
\text { bibir }\end{array}$ \\
\hline 10 & Limfonodus & Tidak Normal & Pembesaran limfonodus mandibularis \\
\hline
\end{tabular}

Sumber: Data hasil pemeriksaan hewan kasus.

Berdasarkan pemeriksaan klinis (Tabel 2 dan 3), anjing kasus mengalami masalah pada sistem pencernaannya yaitu pada rongga mulutnya dan pembengkakan limfonodus. Hal ini terlihat dari perilaku anjing yang enggan menutup mulutnya secara sempurna, air liur menetes berwarna kuning kemerahan, dan mulutnya berbau busuk. Pembengkakan limfonodus terjadi akibat sel-sel yang melawan infeksi dan cairan menumpuk. Gejala klinis (Gambar 1) yang ditemukan pada kasus ini yaitu pembengkakan dan perdarahan pada gusi dan bibir, luka robek dan ulserasi di bibir, plaque di hampir seluruh gigi, dan halitosis mengarahkan kasus ini pada penyakit radang rongga mulut, yakni Stomatitis. Pada kasus ini stomatitis terjadi akibat adanya akumulasi plaque di gigi yang 
kemudian menyebabkan peradangan. Adanya plaque di hampir seluruh giginya, peradangan pada berbagai jaringan di rongga mulut, lesi ulser dan nekrosis yang ditandai dengan mukosa berwarna keabu-abuan sesuai pernyataan Berata, Winaya, Adi, Adnyana, \& Karden (2011), menandakan bahwa peradangan telah berlangsung kronis. Hal ini sesuai pernyataan
Mortazavi, Safi, Baharvand, \& Rahmani (2016) bahwa pada lesi kronis, ulsernya dalam dengan tepian berwarna merah keunguan atau kecoklatan, sehingga stomatitis yang terjadi pada hewan kasus ini, yakni disertai lesi ulser, nekrosis lapisan mukosa, dan berlangsung kronis disebut CCUS.

Tabel 3. Hasil pemeriksaan sistem pencernaan hewan kasus

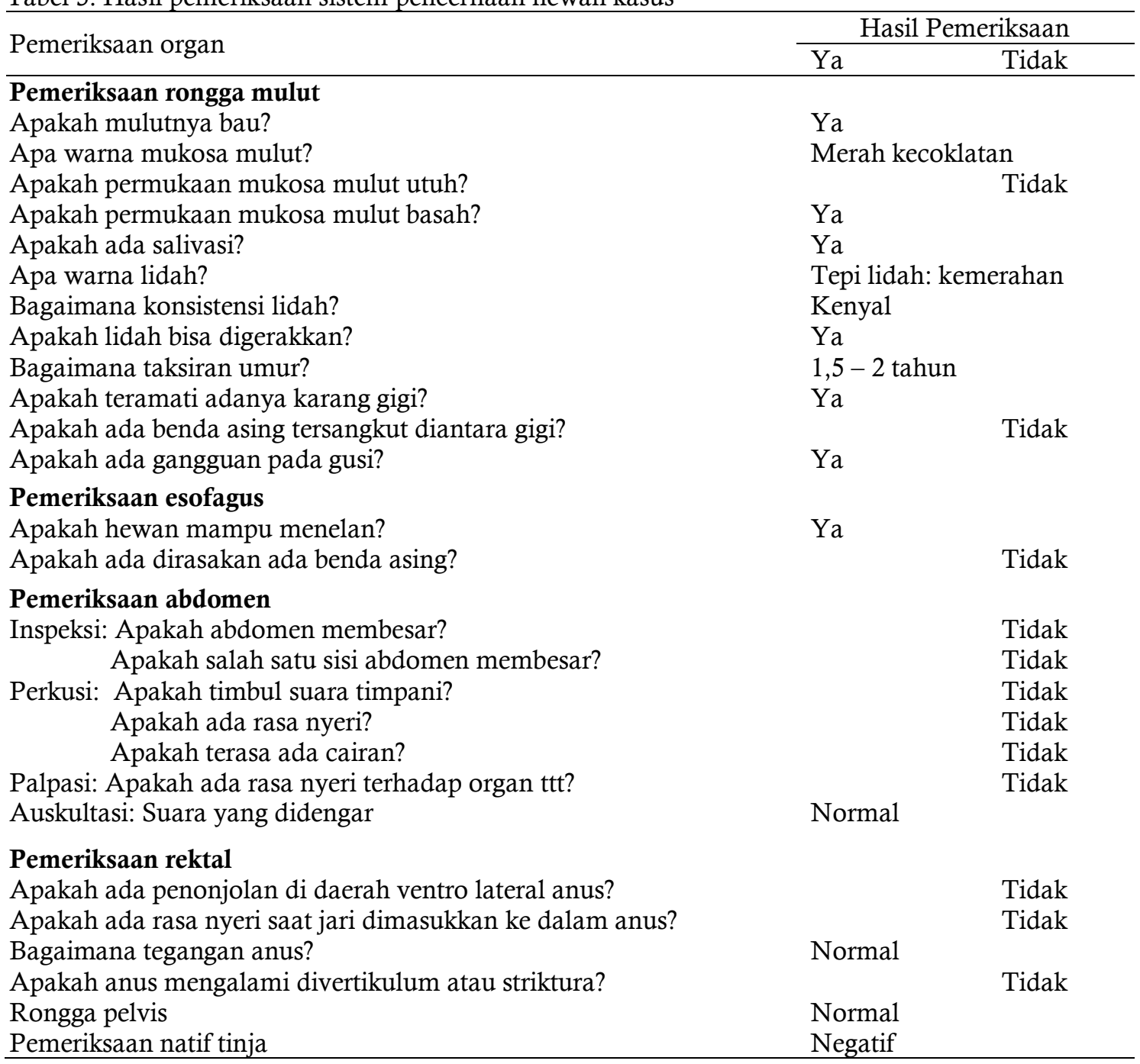

*Sumber: Data hasil pemeriksaan hewan kasus.

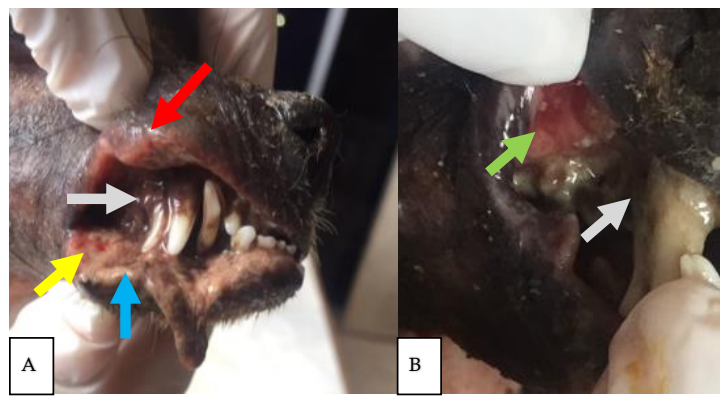

Gambar 1. (A) dan (B) Tanda klinis pada hewan kasus Canine Chronic Ulcerative Stomatitis. Pembengkakan pada bibir $(\triangle)$, perdarahan $(\triangle)$, ulserasi $(\triangle)$, nekrosis $(\triangle)$, karang gigi $(\triangle)$. 
Hasil pemeriksaan darah (Tabel 4) menunjukkan bahwa anjing kasus mengalami Anemia normositik normokromik. Hal ini ditandai dengan rendahnya kadar RBC dan HB pada anjing kasus, namun kadar MCV dan MCHC masih dibatas normal. Selain itu, hewan kasus juga mengalami peningkatan kadar monosit dalam darah. Anemia normositik normokromik dan peningkatan kadar monosit pada hewan kasus ini terjadi karena peradangan pada CCUS berlangsung kronis. Hal ini sesuai dengan pernyataan Fenta, Nuru, Yemane, Asres,
\& Wube (2020) bahwa anemia normositik normokromik paling sering terjadi sebagai akibat dari infeksi kronis dan penyakit sistemik. Lebih lanjut, Dutta \& Nahrendorf (2014) mengemukakan bahwa peradangan akut dan kronis menyebabkan monositosis sistemik. Hewan kasus juga mengalami neutrofilia, yakni meningkatnya kadar neutrofil dalam darah diatas normal. Peningkatan kadar neutrofil ini akibat adanya infeksi bakteri pada penderita CCUS, sesuai pernyataan Kumar, Abbas, \& Aster (2017) bahwa neutrofilia dapat disebabkan karena adanya infeksi bakteri.

Tabel 4. Hasil pemeriksaan hematologi rutin hewan kasus

\begin{tabular}{lllll}
\hline Hematologi Rutin & Hasil & Nilai Rujukan* & Satuan & Keterangan \\
\hline White Blood Cell $(\mathrm{WBC})$ & 13,8 & $6,0-15,0$ & $\mathrm{x} 10^{9} / \mathrm{L}$ & Normal \\
Red Blood Cell $(\mathrm{RBC})$ & 2,61 & $5,5-8,5$ & $\mathrm{x} 10^{12} / \mathrm{L}$ & Menurun \\
Haemoglobine $(\mathrm{HB})$ & 56 & $132-190$ & $\mathrm{~g} / 1$ & Menurun \\
Packed Cell Volume (PCV) & 16 & $40-56,0$ & $1 / 1$ & Menurun \\
Monosit & 8 & $3-10$ & $\%$ & Normal \\
Eosinofil & 0 & $2-10$ & $\%$ & Normal \\
Basofil & 0 & Jarang & $\%$ & Normal \\
Lymposit & 16 & $12-30$ & $\%$ & Normal \\
Neutrofil & 76 & $60-70$ & $\%$ & Meningkat \\
Mean Corpuscular Volume (MCV) & 61,30 & $60,0-77,0$ & $\mathrm{fl}$ & Normal \\
Mean Corpuscular Haemoglobine & 350 & $320-360$ & $\mathrm{~g} / \mathrm{L}$ & Normal \\
Concentration (MCHC) & & & &
\end{tabular}

*Sumber: Day, Mackin, \& Littlewood (2012).

Pada kasus ini, radang gusi berkembang menjadi radang rongga mulut, yakni melibatkan lidah dan bibir, dimana bibir hewan kasus mengalami pembengkakan dan robek. Oleh karena semakin banyaknya luka tanpa ada pengobatan serta tingkat higienitas rongga mulut yang rendah pada hewan kasus, sehingga menyebabkan bertambah parahnya infeksi hingga muncul lesi nekrosis pada mukosa mulut, dan adanya luka serta infeksi bakteri di rongga mulut yang menyebabkan air liur yang menetes berwarna kuning kemerahan dan keruh karena bercampur darah dan disertai bau nafas yang tidak sedap (halitosis).

Pada kasus ini anjing diberi terapi pengobatan menggunakan antibiotik Amoxicilin sebagai terapi causatif dan antiradang Meloxicam sebagai terapi simptomatif, sedangkan untuk terapi supportif diberikan ferrous sulfat untuk membantu meningkatkan produksi sel darah merah, vitamin $\mathrm{C}$ untuk membantu mengatasi rapuhnya pembuluh darah pada rogga mulut, dan infus $\mathrm{NaCl}$ untuk rehidrasi dan memaintenance kondisi pasien. Tindakan membersihkan mulut menggunakan larutan antiseptik juga dilakukan pada kasus ini, yaitu menggunakan larutan antiseptik, untuk menjaga kebersihan rongga mulut dan mencegah semakin berkembangnya infeksi tersebut. Selain itu, dental scalling juga perlu dilakukan untuk membersihkan plaque pada gigi agar mengurangi kejadian kambuhnya stomatitis, namun pada kasus ini belum dilakukan karena keadaan rongga mulut yang masih rapuh. Penanganan ini sesuai dengan Pawitri (2018) bahwa managemen penyakit stomatitis kronis yang utama adalah menjaga kebersihan rongga mulut, pemberian antimikrobial, dan anti inflamasi.

Amoxicillin dapat menjadi pilihan untuk pengobatan infeksi gigi dan rongga mulut karena Amoxicillin atau kombinasi Amoxicillin-Asam Klavulanic telah terbukti sangat baik untuk pengobatan pasien dengan masalah periodontal, sebagaimana yang telah dilaporkan oleh Prakasam, Elavarasu, \& Natarajan (2012). Amoxicillin merupakan antibiotik golongan beta-laktamase yang mekanisme kerjanya dengan cara menghambat proses transpeptidasi dan menyebabkan aktifasi enzim autolisis pada dinding sel bakteri sehingga terjadi kematian bakteri (Akhavan, Khanna, \& Vijhani, 2020).

Meloxicam adalah salah satu obat antiinflamasi non steroid penghambat enzim siklooksigenase (COX) yang terbukti efektif digunakan sebagai analgesik pasca operasi dan untuk terapi pengobatan nyeri yang berhubungan 
dengan gangguan muskuloskeletal (Charlton, Benito, Simpson, Freire, \& Lascelles, 2013), namun pemberian Meloxicam juga efektif digunakan pada penderita Stomatitis, sebagaimana yang dilaporkan Pawitri (2018).

Vitamin C atau Ascorbid acid merupakan vitamin yang dapat diberikan pada penderita stomatitis. Hal ini dikarenakan vitamin C dapat membantu memperbaiki rapuhnya pembuluh darah pada penderita stomatitis. Vitamin C berperan dalam melindungi pembuluh darah dengan meningkatkan sintesis dan pengendapan kolagen tipe IV di membran basal, merangsang proliferasi endotel dan menghambat apoptosis, membuang radikal bebas, membantu mengatur aliran darah, dan mungkin juga peran dalam mencegah disfungsi endotel yang merupakan tanda paling awal dari banyak penyakit (May \& Harrison, 2013).

Ferrous sulfate adalah suplemen zat besi yang dapat diberikan pada penderita anemia, hal ini dikarenakan zat besi merupakan salah satu komponen penting dalam pembentukan darah, sebagaimana Winter, Bazydlo, \& Harris (2014) mengemukakan bahwa zat besi adalah salah satu komponen penting dalam tubuh, diantaranya adalah berperan dalam proses transport oksigen (hemoglobin), tempat penampungan oksigen jangka pendek (mioglobin), metabolisme energi, dan berbagai aktifitas sistem enzim lainnya, sehingga pemberian suplemen ini dapat memperbaiki keadaan pada pasien anemia dengan cara menyediakan komponen untuk produksi sel darah merah.

Terapi cairan merupakan tindakan yang penting dilakukan untuk hewan dalam kondisi kritis atau memerlukan perawatan intensif. Pemberian terapi cairan pada kasus ini dilakukan karena hewan mengalami dehidrasi dan untuk memaintenance kondisi hewan.

Penanganan hewan kasus pada $\mathrm{H}+4$ menunjukkan perkembangan yang cukup baik. Hal ini ditandai dengan berubahnya air warna air liur yang menetes menjadi warna semakin bening dan bengkak pada bibir berkurang. Meskipun keadaan rongga mulut semakin membaik, namun pada $\mathrm{H}+6$ pengobatan, hewan mati. $\mathrm{Hal}$ ini kemungkinan disebabkan oleh kondisi malnutrisi dan anemia parah pada hewan kasus, dimana seharusnya pada kasus ini perlu dilakukan transfusi darah untuk mengatasi anemia pada pasien anjing tersebut.

\section{Kesimpulan}

Anjing Pomeranian bernama Piki didiagnosis menderita Canine Chronic Ulcerative Stomatitis (CCUS). Pengobatan dilakukan dengan pemberian amoxicilin, meloxicam, vitamin c, ferrous sulfat, dan terapi cairan menggunakan $\mathrm{NaCl}$. Penanganan hewan kasus pada $\mathrm{H}+4$ menunjukkan perkembangan yang cukup baik, namun pada $\mathrm{H}+6$ pengobatan, hewan mati. Hal ini kemungkinan disebabkan oleh kondisi malnutrisi dan anemia parah pada hewan kasus yang seharusnya pada kasus ini perlu dilakukan transfusi darah. Pada kasus serupa, dianjurkan untuk membersihkan mulut pasien dengan larutan antiseptik setelah makan untuk menjaga kebersihan rongga mulut. Pembersihan plaque dan karang gigi (scalling) juga perlu dilakukan setelah kondisi hewan stabil.

\section{Ucapan Terima Kasih}

Terima kasih kepada seluruh staf Laboratorium Ilmu Penyakit Dalam Veteriner, Fakultas Kedokteran Hewan, Universitas Udayana yang telah memfasilitasi, membantu penanganan, dan membimbing kasus ini, serta teman-teman kelompok koasistensi 13C yang telah membantu penulis selama studi kasus berlangsung.

\section{Daftar Pustaka}

Akhavan, B. J., Khanna, N. R., \& Vijhani, P. (2020). Amoxicillin. StatPearls Publishing.

Anderson, J. G., Peralta, S., Kol, A., Kass, P. H., \& Murphy, B. (2017). Clinical and histopathologic characterization of canine chronic ulcerative stomatitis. Veterinary Pathology, 54(3), 511-519. https://doi.org/ $10.1177 / 0300985816688754$

Berata, I., Winaya, I., Adi, A., Adnyana, I., \& Kardena, I. (2011). Patologi Veteriner Umum. Denpasar: Swasta Nulus.

Boutoille, F., \& Hennet, P. (2011). Maxillary osteomyelitis in two Scottish terrier dogs with chronic ulcerative paradental stomatitis. Journal of Veterinary Dentistry, 28(2), 96-100. https://doi.org/10.1177/08 9875641102800206

Charlton, A. N., Benito, J., Simpson, W., Freire, M., \& Lascelles, B. D. X. (2013). Evaluation of the clinical use of tepoxalin and meloxicam in cats. Journal of Feline Medicine and Surgery, 15(8), 678-690. https: //doi.org/10.1177/1098612X12473994

Day, M. J., Mackin, A., \& Littlewood, J. D. (2012). BSAVA Manual of Canine and Feline Haematology and Transfusion Medicine (2nd ed.; M. J. Day \& B. Kohn, eds.). 
Quedgeley: British Small Animal Veterinary Association.

Dutta, P., \& Nahrendorf, M. (2014). Regulation and consequences of monocytosis. Immunological Reviews, 262(1), 167-178. https://doi.org/10.1111/imr.12219

Fenta, D. A., Nuru, M. M., Yemane, T., Asres, Y., \& Wube, T. B. (2020). Anemia and related factors among highly active antiretroviral therapy experienced children in Hawassa comprehensive specialized hospital, Southern Ethiopia: Emphasis on patient management. Drug, Healthcare and Patient Safety, 12, 49-56. https://doi.org/ 10.2147/DHPS.S230935

Fleming, S., Gill, P., Jones, C., Taylor, J. A., Van den Bruel, A., Heneghan, C., ... Thompson, M. (2015). The diagnostic value of capillary refill time for detecting serious illness in children: a systematic review and meta-analysis. PloS One, 10(9), e0138155. https: //doi.org/ 10.1371/ journal.pone.0138155

Graves, M. T., \& Ivey, J. L. (2018). Ulcerative stomatitis associated with ingestion of broomsedge hay in a horse. Veterinary Record Case Reports, 6(4), e000660. https:// doi.org/10.1136/vetreccr-2018-000660

Kumar, V., Abbas, A. K., \& Aster, J. C. (2017). Robbins: Basic Pathology (10th ed.). Philadelphia, Pensilvania: Elsevier Health Sciences.

May, J. M., \& Harrison, F. E. (2013). Role of vitamin $C$ in the function of the vascular endothelium. Antioxidants \& Redox Signaling, 19(17), 2068-2083. https://doi. org/10.1089/ars.2013.5205

Mortazavi, H., Safi, Y., Baharvand, M., \& Rahmani, S. (2016). Diagnostic features of common oral ulcerative lesions: an updated decision tree. International Journal of Dentistry, 2016, 1-14. https://doi.org/10. $1155 / 2016 / 7278925$

Pawitri, D. (2018). Chronic ginggivostomatitis pada kucing lokal. ARSHI Veterinary Letters, 2(2), 23-24.

Prakasam, A., Elavarasu, S. S., \& Natarajan, R. K. (2012). Antibiotics in the management of aggressive periodontitis. Journal of Pharmacy \& Bioallied Sciences, 4(Suppl 2), S252-S255. https://doi.org/10.4103/0975 $-7406.100226$
Widodo, S., Sajuthi, D., Choliq, C., Wijaya, A., Wulansari, R., \& Lelana, A. R. P. (2011). Diagnostik Klinik Hewan Kecil (S. Widodo, ed.). Bogor: IPB Press.

Winter, W. E., Bazydlo, L. A. L., \& Harris, N. S. (2014). The molecular biology of human iron metabolism. Laboratory Medicine, 45(2), 92-102. https://doi.org/10.1309/LMF28 S2GIMXNWHMM 